\title{
Occurrence of the genus Amblyceps Blyth (Teleostei: Amblycipitidae) from the Indo-Bhutan streams of the Brahmaputra drainage of Assam, India
}

\author{
Sewali Pathak ${ }^{1 *}$, Mrigendra M. Goswami ${ }^{2}$ and Nripendra Nath Sarma ${ }^{3}$ \\ ${ }^{1}$ Department of Zoology, Bijni College, Bijni, Chirang-783390 (Assam), INDIA \\ ${ }^{2}$ Department of Zoology, Gauhati University, Guwahati-781014 (Assam), INDIA \\ ${ }^{3}$ Department of Zoology, Bajali College, Pathsala, Pin-781346, Barpeta (Assam), INDIA \\ *Corresponding author. E-mail: sewalip@gmail.com \\ Received: December 23, 2013; Revised received: February 28, 2014; Accepted: April 30, 2014
}

\begin{abstract}
Three species of the genus Amblyceps, namely, A. apangi, A. arunachalensis, $A$. mangois are described from Kanamakra and Langkhar $\left(26^{\circ} 45^{\prime} 0^{\prime \prime}-26^{\circ} 48^{\prime} 0^{\prime \prime} \mathrm{N}\right.$ and $\left.90^{\circ} 35^{\prime} 0^{\prime \prime}-90^{\circ} 40^{\prime} 0^{\prime \prime} \mathrm{E}\right)$ hill streams of Chirang district of Assam. The torrent catfishes are distinguished within the genera on the basis of their general appearance of the body and the caudal fin structure, adipose fin, eye diameter, inter-orbital space, fold on lip and number of vertebrae. The caudal peduncle height for $A$. apangi (12.36-12.73\% SL), $A$. mangois (14.25-15.36\% SL) and $A$. arunachalensis (10.01-11.42\% SL), caudal peduncle length for $A$. apangi (20.29-20.87\% SL), $A$. arunachalensis $(22.00-22.11 \%$ $\mathrm{SL})$ and $A$. mangois (19.09-19.31\% SL) and other taxonomic details of the congeners with their distributional status are discussed.
\end{abstract}

Keywords: Brahmaputra drainage, Catfish diversity, Foot hill streams, Siluriformes

\section{INTRODUCTION}

Blyth (1858) described the genus Amblyceps from Myanmar. Ng and Kottelat (2000), Ng (2001, 2005) reviewed the genus Amblyceps Blyth and identified 13 valid species of Amblyceps viz. Amblyceps mangois (Hamilton, 1822), A. laticeps (McClelland, 1842), A. caecutiens Blyth, 1858, A. murraystuarti Chaudhuri, 1919, A. foratum $\mathrm{Ng}$ and Kottelat, 2000, A. mucronatum $\mathrm{Ng}$ and Kottelat, 2000, A. platycephalus $\mathrm{Ng}$ and Kottelat, 2000, A. serratum $\mathrm{Ng}$ and Kottelat, 2000, A. variegatum $\mathrm{Ng}$ and Kottelat, 2000, A. macropterus $\mathrm{Ng}$, 2001, A. carinatum Ng, 2005, A. tenuispinis Blyth, 1858, A. apangi Nath and Dey, 1989, and considered A. arunachalensis Nath and Dey, 1989 a synonym of A. mangois. Vishwanath and Linthoingambi (2007) redescribed A. arunachalensis Nath and Dey, 1989 and are recognized as valid species in this study. Vishwanath and Linthoingambi, 2008 recognized two valid species $A$. torrentis and A. tuberculatum from the Chindwin basin in Manipur and thus the genus Amblyceps includes 16 valid species. Two species A. apangi and A. arunachalensis reported earlier from Arunachal Pradesh (Nath and Dey, 1989) are recorded now from the Langkhar stream at Amteka and Kanamakra stream at Amguri $\left(26^{\circ} 45^{\prime} 0^{\prime \prime}-26^{\circ} 48^{\prime} 0^{\prime \prime} \mathrm{N}\right.$ and $90^{\circ} 35^{\prime} 0^{\prime \prime}-90^{\circ} 40^{\prime} 0^{\prime \prime} \mathrm{E}$ ) in Chirang District of Assam, which constitutes a new occurrence record in the type locality of Assam.

\section{MATERIALS AND METHODS}

The specimens of Amblyceps were procured from Langkhar and Kanamakra streams of Chirang District.
Measurements were made on the left side of the specimens by using digital calipers to the nearest tenth of a millimeter following $\mathrm{Ng}$ and Kottelat (2000). The collection and preservation of fishes were made following Brooks (2011). Parts of body are expressed as percentages of standard length (SL) and the subunits of the head as proportions of head length (HL). The fin rays were counted under binocular stereo-zoom microscope (Leica ATC 2000) using transmitted light. Materials examined in this study have been deposited to Gauhati University Zoological Museum (GUZM). Specimens were processed for vertebrae counts following Hollister (1934) and counted following Roberts (1989). Valid name of genera and current systematic status of species were adopted from California Academy of Science web site (www.calacademy.org/catalogue).

\section{OBSERVATIONS}

Amblyceps arunachalensis Nath and Dey, 1989 (Fig.1A)

Material examined: GUZM 0051, $43.16 \mathrm{~mm} \mathrm{SL}$, Kanamakra hill stream (Amguri- $30 \mathrm{~km}$ from Bijni town) $26^{\circ} 45^{\prime} 0^{\prime \prime}-26^{\circ} 48^{\prime} 0^{\prime \prime} \mathrm{N}$ and $90^{\circ} 35^{\prime} 0^{\prime \prime}-90^{\circ} 40^{\prime} 0^{\prime \prime} \mathrm{E}$, in Chirang district of Assam, 2011 (coll. 10 ${ }^{\text {th }}$ May). MUMF 6401, 3, 68.1-82.7 mm SL; GUZM 0052, 3, 39.25-49 mm SL, Langkhar (Amteka- $42 \mathrm{~km}$ from Bijni town) and Kanamakra (Amguri $-30 \mathrm{~km}$ from Bijni town) hill streams in Chirang district $\left(26^{\circ} 45^{\prime} 0^{\prime \prime}-\right.$ $26^{\circ} 48^{\prime} 0^{\prime \prime} \mathrm{N}$ and $90^{\circ} 35^{\prime} 0^{\prime \prime}-90^{\circ} 40^{\prime} 0^{\prime \prime} \mathrm{E}$ ) of Assam, 2011 (coll. $25^{\text {th }}$ May).

Diagnosis: Morphometric characters are given in 
table 1. Lower jaw longer than upper jaw; rictal fold reduced; head round, its maximum width 88.63$89.24 \%$ HL, depth at occiput $70.58-71.39 \%$ HL; eye diameter 7.35-8.27\% HL; interorbital space 44.30$44.38 \% \mathrm{HL}$; gape width 50.80-51.07\% HL; caudal peduncle height $50.5-51.2 \%$ its length; HL 18.5$19.0 \%$ SL; skin with tubercle, pinnate like rays of caudal fin present; upper lobe of caudal longer than lower lobe; adipose fin widely separated from caudal fin.

Description: Body elongated and compressed posterior, head short and rounded, mouth terminal with longer lower jaw than upper, lips with double folds, teeth in upper jaw with narrow band extend posterior on both sides and separated by a narrow gap, whereas the lower jaw in a semicircular band and separated in middle, prominent fold of skin present on opercular flap, fleshy rim of posterior nards an incomplete tube but the anterior nards a complete tube, eyes small and subcutaneous, barbel four pairs and compressed throughout their length, nasal extend up to dorsal end of head, maxillary extends up to middle of pectoral fin base, outer mandibular beyond posterior end of pectoral fin base, inner mandibular extends up to isthmus. Dorsal fin origin vertically through middle length of pectoral fin with 6 rays, dorsal spine hidden beneath skin, adipose fin at vertical level of anal fin origin and separated from caudal fin, pectoral fin extends up to vertically through just behind middle length of dorsal fin base with 7 rays and a smooth spine, pelvic fin origin just beyond vertical level of middle of interdorsal distance with 6 rays, anal fin origin just before vertical level of adipose fin with 9 rays, caudal fin deeply forked with 18-19 rays, upper lobe longer than lower lobe, fins plain, skin tuberculated, lateral line incomplete, body colour brown in fresh, branchiostegal ray 4-5, vertebrae $22+19$ (40).

Colouration: Body colour grey brown in fresh specimen, turned fade brown in preserved specimen. Fins and barbels dull grey, ventral dull grey.

Distribution: Arunachal Pradesh (Brahmaputra basin), Kanamakra and Langkhar hill streams of Chirang District, Assam.

Amblyceps apangi Nath and Dey, 1989 (Fig. 1B)

Material examined: GUZM 0053, $75.80 \mathrm{~mm}$ SL, Langkhar (Amteka- $42 \mathrm{~km}$ from Bijni town) hill stream in Chirang district $\left(26^{\circ} 45^{\prime} 0^{\prime \prime}-26^{\circ} 48^{\prime} 0^{\prime \prime} \mathrm{N}\right.$ and $90^{\circ} 35^{\prime} 0^{\prime \prime}-90^{\circ} 40^{\prime} 0^{\prime \prime} \mathrm{E}$ ) of Assam, 2011 (coll. $13^{\text {th }}$ May). GUZM 0054, 3, 62.27-78.85 mm SL, Langkhar and Kanamakra hill streams (Amteka and Amguri - $42 \mathrm{~km}$ and $30 \mathrm{~km}$ from Bijni town) $26^{\circ} 45^{\prime} 0^{\prime \prime}-26^{\circ} 48^{\prime} 0^{\prime \prime} \mathrm{N}$ and $90^{\circ} 35^{\prime} 0^{\prime \prime}-90^{\circ} 40^{\prime} 0^{\prime \prime} \mathrm{E}$, in Chirang district of Assam, 2011 (coll. 22 ${ }^{\text {nd }}$ May), MUMF 6404, 4, 60.0-77.8 mm SL; MUMF 6408, 2 74.8-81.2 mm SL.

Diagnosis: Morphometric characters are given in table 1. Jaws equal, rictal fold large and well developed, skin smooth, pinnate-like rays absent, adipose fin not confluent with caudal fin but very close to caudal fin, Caudal fin truncate or emarginated, head length 22.9523.60\% SL, head depth 45.44-46.55\% HL, head width 74.38-76.43\% HL, inter-orbital space 27.07-30.2\% HL, gape width $48.56-49.65 \% \mathrm{HL}$, caudal peduncle length 20.29-20.87\% SL, caudal peduncle height 60.61-62.25\% CPL.

Description: Body elongated and gradually com-

Table 1. Morphometric data of three species of genus Amblyceps.

\begin{tabular}{|c|c|c|c|c|c|c|c|c|c|}
\hline \multirow{2}{*}{$\%$ Standard length } & \multicolumn{3}{|c|}{ A. arunachalensis } & \multicolumn{3}{|c|}{ A. apangi } & \multicolumn{3}{|c|}{ A. mangois } \\
\hline & Range (mm) & Mean & SD & Range (mm) & Mean & SD & Range (mm) & Mean & $\mathrm{SD}$ \\
\hline Body depth & $15.42-15.54$ & 15.48 & 0.08 & $13.06-13.21$ & 13.15 & 0.08 & $18.09-18.39$ & 18.24 & 0.21 \\
\hline Body depth at anus & $14.48-14.64$ & 14.56 & 0.11 & $14.19-14.86$ & 14.5 & 0.33 & $14.23-15.44$ & 14.83 & 0.85 \\
\hline Head length & $19.00-19.05$ & 19.02 & 0.03 & $22.95-23.60$ & 23.01 & 0.35 & $20.00-21.83$ & 20.91 & 1.29 \\
\hline Caudal peduncle length & $22.00-22.11$ & 22.05 & 0.07 & $20.29-20.87$ & 20.53 & 0.30 & $19.09-19.31$ & 19.2 & 0.15 \\
\hline Caudal peduncle height & $10.01-11.42$ & 10.71 & 0.99 & $12.36-12.73$ & 12.58 & 0.19 & $14.25-15.36$ & 14.80 & 0.78 \\
\hline Inter-dorsal distance & $25.63-28.28$ & 28.03 & 1.87 & $27.10-30.34$ & 28.86 & 1.63 & $25.09-26.89$ & 25.99 & 1.27 \\
\hline Dorsal fin base length & $10.01-11.18$ & 10.59 & 0.82 & $8.02-8.31$ & 8.19 & 0.15 & $11.18-11.44$ & 11.31 & 0.18 \\
\hline Pectoral fin length & $15.30-15.54$ & 15.42 & 0.16 & $12.28-13.19$ & 12.66 & 0.47 & $14.14-14.94$ & 14.54 & 0.56 \\
\hline Pelvic fin le & $10.57-10.81$ & 10.69 & 0.16 & $10.01-10.29$ & 10.11 & 0.15 & $9.54-10.00$ & 9.77 & 0.32 \\
\hline Anal fin length & $18.16-18.34$ & 18.25 & 0.12 & $14.07-14.61$ & 14.26 & 0.30 & $20.54-20.68$ & 20.61 & 0.09 \\
\hline Pre dorsal length & $28.10-28.78$ & 28.44 & 0.48 & $25.33-26.43$ & 25.74 & 0.59 & $28.04-28.18$ & 28.11 & 0.09 \\
\hline & 14 & 50.28 & 0.22 & $50.17-52.11$ & 50.82 & 1.11 & 49.09 & 49.08 & .007 \\
\hline $\begin{array}{l}\text { Pre a } \\
\% \mathbf{H e}\end{array}$ & $63.67-63.69$ & 63.68 & 0.01 & $63.86-65.96$ & 64.89 & 1.05 & 63.38 & 63.23 & 0.21 \\
\hline Head depth at nape & $70.58-71.39$ & 70.98 & 0.57 & -46.55 & 46.09 & 0.57 & -70.52 & 70.47 & 0.06 \\
\hline Head depth at eye & $47.31-47.45$ & 47.38 & 0.09 & $40.22-42.69$ & 41.12 & 1.35 & $49.13-50.31$ & 49.72 & 0.83 \\
\hline Head width at eye & $80.10-80.21$ & 80.15 & 0.07 & $68.02-71.83$ & 69.75 & 1.92 & $70.43-71.89$ & 71.16 & 1.03 \\
\hline Snout length & $30.44-30.64$ & 30.54 & 0.14 & $34.01-36.09$ & 34.93 & 1.05 & $23.15-23.47$ & 23.31 & 0.22 \\
\hline Eye diameter & $7.35-8.27$ & 7.81 & 0.65 & $8.16-8.62$ & 8.34 & 0.24 & $11.30-11.57$ & 11.43 & 0.19 \\
\hline Inter orbital distance & $44.30-44.38$ & 44.34 & 0.05 & $27.07-30.02$ & 28.8 & 1.53 & $48.38-48.69$ & 48.53 & 0.21 \\
\hline Wide of gape of mouth & $50.80-51.07$ & 50.93 & 0.19 & $48.56-49.65$ & 49.26 & 0.61 & $50.43-50.52$ & 50.47 & 0.06 \\
\hline Inter nostril distance & 19.89-20.05 & 19.97 & 0.11 & $17.00-17.35$ & 17.19 & 0.17 & $19.13-19.47$ & 19.3 & 0.24 \\
\hline
\end{tabular}


pressed posterior, head narrow and depressed, mouth terminal with slightly longer upper jaw than lower, lips thick with single fold, rictal fold very well developed, teeth in upper jaw in broad band with posterior extensions on both sides and separated by a narrow gap, whereas lower jaw in a semicircular band and separated in middle, prominent fold of skin present posterior to opercular flap, fleshy rim of posterior nards an incomplete tube but the anterior nards a complete tube, eyes small and subcutaneous, barbels compressed throughout their length, nasal barbels reaches to about $3 / 4$ of head length, maxillary and outer mandibular reached beyond posterior base of pectoral fin, inner mandibular reaches about $3 / 4$ of head length.

Dorsal fin with a weak spine and 5-6 rays' origin vertically through middle length of pectoral fin, adipose fin origin at vertical level of posterior base of anal
Langkhar hill stream (Amteka- $42 \mathrm{~km}$ from Bijni town) in Chirang district $\left(26^{\circ} 45^{\prime} 0^{\prime \prime}-26^{\circ} 48^{\prime} 0^{\prime \prime} \mathrm{N}\right.$ and

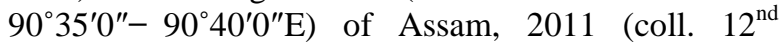
April). GUZM 0056, 3, 43.50- 55.00 mm SL, Langkhar and Kanamakra hill stream (Amteka and Amguri - $42 \mathrm{~km}$ and $30 \mathrm{~km}$ from Bijni town) in Chirang district $\left(26^{\circ} 45^{\prime} 0^{\prime \prime}-26^{\circ} 48^{\prime} 0^{\prime \prime} \mathrm{N}\right.$ and $90^{\circ} 35^{\prime} 0^{\prime \prime}-90^{\circ} 40^{\prime}$

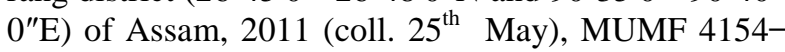
4155, 2, 42.5-50.0 mm SL.

Diagnosis: Morphometric characters are given in table 1. Jaws equal, lateral line absent, caudal fin deeply forked, adipose fin not confluent with caudal fin but free with rounded posterior margin, skin smooth, folds on lips double, rictal fold reduced, number of vertebrae 34-36, pinnate like rays present on caudal fin rays, upper lobe of caudal fin is slightly longer and pointed, head length $20.0-21.83 \%$ SL, caudal peduncle length

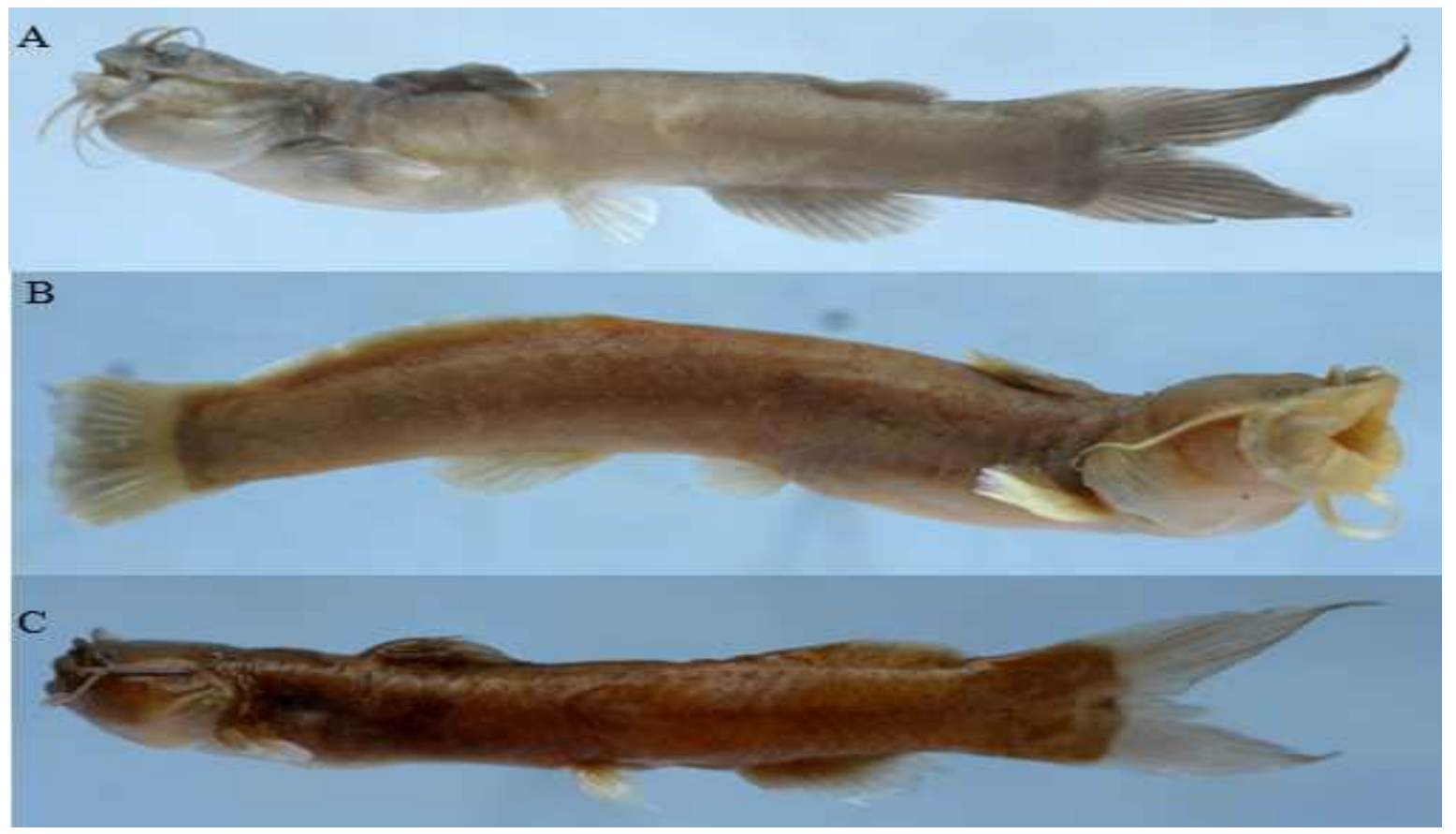

Fig.1. Showing image of A-A. arunachalensis (43.16 mm SL), B-A. apangi (75.80 mm SL), C-A. Mangois (48.75 mm SL).

fin, Pectoral fin with 7 rays and extending vertically through just behind middle length of dorsal fin base, pelvic fin with 6 rays, anal fin with 7 rays, caudal fin emarginated with 18-20 rays, lateral line pores at tip of short tube like structure microscopically, pores arranged in pairs and each pair separated by a short gap, skin smooth, lateral line complete, fins plain, body colour olive brown in fresh, branchiostegal rays 4-5, Vertebrae 24+19 (43).

Colouration: Body colour in fresh specimen olive grey, turned light olive brown in preserved specimens. Fins and barbels pale olive brown, ventral pale white.

\section{Distribution: Arunachal Pradesh, Nagaland} (Brahmaputra basin), Ng (2005) reported it from West Bengal (Tista drainage); Kanamakra and Langkhar hill streams of Chirang District, Assam.

Amblyceps mangois Hamilton, 1822 (Fig. 1C)

Material examined: GUZM 0055, $48.75 \mathrm{~mm}$ SL,
19.09-19.31\% SL, body depth 18.09-18.39\% SL, head depth $70.43-70.52 \%$ HL, eye diameter $11.30-11.57 \%$ HL, caudal peduncle height 73.79-80.47\% CPL.

Description: Body elongated and gradually compressed posterior, abdomen rounded, head short and rounded, mouth terminal, lips with double folds, teeth in upper jaw as narrow band with posterior extensions on both sides and separated by a narrow gap whereas lower jaw in a semicircular band, separated in middle, prominent fold of skin present posterior to opercular flap, fleshy rim of posterior nards an incomplete tube with posterior notch while that of the anterior nards a complete tube, eyes small and subcutaneous, barbel four pairs, compressed throughout their length, nasal extends up to dorsal end of head, maxillary extends up to middle of pectoral fin base, outer mandibular beyond posterior end of pectoral fin base, inner mandibular extends up to isthmus. 
Dorsal fin origin vertically through middle length of pectoral fin with a weak spine and 6 rays, adipose fin at vertical level of anal fin origin, pectoral fin with a weak spine and 7 rays, pelvic fin with 6 rays, anal fin with 9 rays, caudal fin 20-22 rays, caudal fin deeply forked with pinnate like rays, upper lobe slightly longer with pointed end, two outer most branched rays longest, skin smooth, lateral line absent, fins plain, tinged grey, body colour brown in fresh, branchiostegal rays 4, vertebrae- $19+19$ (38).

Colouration: Body colour in fresh specimen grey brown, turned dull grey brown in preserved specimen. Fins and barbels dull grey, ventrals dull white.

Distribution: Assam: Kanamakra and Langkhar hill streams of Chirang District, Manipur: Jiri river (Brahmaputra basin), Chatrickong and Maklang river (Chindwin basin), all along the foothills of Himalayas, Bangladesh, Northern Myanmar, Nepal, Thailand.

\section{DISCUSSION}

Hamilton (1822) described A. mangois (Amblycceps caecutiens Blyth=Pimelodus mangois) from the Northern Bihar. Day (1878) described A. mangois from India, Burma (Myanmar) and Ceylon (Sri Lanka) and considered $A$. caecutiens and A. tenuispinis as synonyms. Chaudhuri (1919) described A. murraystuarti (type locality: Putao plains) from Upper Burma. Shaw and Shebbeare (1937) reported $A$. species of one with deeply forked caudal fin and other with slightly forked audal fin and also reffered A. mangois along with diagram having free, short adipose. Misra (1976) reported two species of $A$. namely $A$. mangois (Hamilton, 1822) and Olyra leticeps (McClelland, 1842). However, Talwar and Jhingran (1991) described only the species A. mangois as monotypic with truncate or emarginated caudal fin without diagram. Jayaram (1999) described A. mangois with truncate or emerginate to varying degree of caudal fin while the description of caudal fin does not correspond with the diagram shown as forked caudal fin. Sen (1985) reported four species of Amblyceps as A. leticeps, A. horai, A. mangois and A. tenuispinis with their definite distinguishing characteristics. Nath and Dey (2000) has given the systematic account of A. apangi, A. arunachalensis and A. mangois reported from Arunachal Pradesh. Blyth have been diagnosed on the basis of the key to species of the genus Amblyceps, by the present or absent of lateral line, equal or unequal of jaws, shape of caudal fin, maxillary barbel length, adipose dorsal free or confluent (Talwar and Jhingran, 1991); the anterior nostril lying on anterior to the base of the nasal barbel, and both lips with double folds (Chen and Lundberg, 1995); a prominent cup-like skin flap above the base of the pectoral spine (Hora, 1933); Present or absent of pinnate like rays on caudal fin $(\mathrm{Ng}$ and Kottelat, 2000). They differentiate the three species on the basis of caudal fin structure, nature of lateral line, maxillary barbel length and length of adipose fin. $\mathrm{Ng}$ (2005) observed the species A. apangi which showed the similarity with $A$. murraystuartii Chaudhuri except its longer head, body colour and number of vertebrae. Vishwanath and Linthoingambi (2007) redescribed $A$. apangi and distinguished it from $A$. mangois and $A$. arunachalensis in having larger rictal folds, depressed head and body, intermediate caudal peduncle height and absence of pinnate like rays on caudal fin. However, as referred from comparative materials A. arunachalensis differ from A. mangois in having longer and slender caudal peduncle, longer upper lobe of caudal peduncle fin, narrower inter orbital space, smaller eyes and longer lower jaw than upper. Both species have pinnate like rays on anterior margins of caudal fin rays. Vishwanath and Linthoingambi (2007) reported the values for $A$. apangi (pectoral fin length 12.5-13.3\% SL and pelvic fin length 10.0-10.2\% SL) and Humtsoe and Bordoloi (2009) reported the values for A. apangi (pectoral-fin length $10.2-14.2 \%$ SL and pelvic-fin length 7.3$10.9 \%$ SL). As per our works, the species of Amblyceps have been distinguished from the congeners based on the taxonomic differentiation of certain parameters in having the caudal peduncle length for $A$. apangi (20.29-20.87\% SL), A. arunachalensis (22.00$22.11 \%$ SL) and A. mangois (19.09-19.31\% SL), and the reported values of Vishwanath and Linthoingambi, 2008 for A. torrentis (21.0-24.3\% SL) and A. tuberculatum (21.2-22.4\% SL). The caudal peduncle height for A. apangi (12.36-12.73\% SL), A. mangois (14.25$15.36 \% \mathrm{SL})$ and $A$. arunachalensis (10.01- $11.42 \%$ $\mathrm{SL})$ and the reported values of A. torrentis (13.8$15.6 \% \mathrm{SL})$ and $A$. tuberculatum (14.0-14.1\% SL).

Body depth at anus for $A$. apangi (14.19-14.86\% SL), A. arunachalensis (14.48-14.64\% SL) and A. mangois (14.23- $15.44 \%$ SL) and the reported values of A. torrentis (15.3-17.3\% SL), and A. tuberculatum (13.6-16.8\% SL); Inter dorsal distance for A. apangi (27.10-30.34\% SL), A. arunachalensis (25.63-28.28\% SL) and A. mangois (25.09-26.89\% SL) and the reported values of $A$. tuberculatum ( $27.8-28.0 \%$ SL) and $A$. torrentis (27.9-39.8\% SL); Adipose fin base length for A. apangi (15.21-15.89\% SL), A. arunachalensis (17.14-17.32\% SL) and A. mangois (17.24$17.41 \%$ SL); Head depth for A. apangi (45.44-46.55\% HL), A. arunachalensis $(70.58-71.39 \% \mathrm{HL})$ and $A$. mangois $(70.43-70.52 \% \mathrm{HL})$; and the reported values of Vishwanath and Linthoingambi, 2008 for A. torrentis $(55-65 \% \mathrm{HL})$ and A. tuberculatum (57$67 \% \mathrm{HL}) ;$ Head depth at eye for A. arunachalensis (47.31-47.45\% HL), A. apangi (40.22-42.69\% HL) and $A$. mangois (49.13-50.31\% HL) and the reported values of Vishwanath and Linthoingambi, 2008 for $A$. tuberculatum (42-48\% HL) and A. torrentis (40-48\% $\mathrm{HL})$; Head width at eye for A. Apangi (68.02-71.83\% $\mathrm{HL}), \quad$ A. arunachalensis $(80.10-80.21 \%$ HL) and A. mangois (70.43-71.89\% HL) and the reported values of A. torrentis (69-78\% HL) and A. tuberculatum (71-76\% HL); Inter orbital distance for A. arun- 
achalensis (44.30-44.38\% HL), A. apangi (27.07$30.02 \% \mathrm{HL}$ ) and A. mangois (48.38-48.69\% HL) and the reported values of A. tuberculatum (41-45\% HL) and $A$. torrentis (29-37\% HL); Gape width for $A$. apangi (48.56-49.65\% HL), A. arunachalensis (50.80$51.07 \% \mathrm{HL})$ and $A$. mangois $(50.43-50.52 \% \mathrm{HL})$ and the reported values of A. torrentis (45-54\% HL) and A. tuberculatum (56-57\% HL).

Comparative material: A. apangi: MUMF 6404, 2, 60-77.8 mm SL; India: Arunachal Pradesh: Doymukh: Dikrong River, Brahmaputra basin.

A. arunachalensis: MUMF 6401, 3, 68.1-82.7 mm SL; Doymukh: Dikrong River: Arunachal Pradesh.

A. mangois: MUMF 4154-4155, 2, 42.5-50 mm SL; Manipur-Assam border, Jiri River.

A. murraystuarti: NRM 40944, 1,112.4 mm SL; NMR 40960, 5, 82.7-106 mm SL; Myanmar: Kachin state, Putao (Irrawady basin).

A. torrentis: MUMF 6168-6169, 6171-6174, 6, 33.8139 mm SL; India: Manipur: Ukhrul district, Chindwin drainage.

A. tuberculatum: MUMF 6179-6181, 3, 69.4-76.3 mm SL; India: Manipur: Ukhrul district, Chindwin drainage.

\section{Conclusion}

The specimens of Amblyceps were collected from the stream of shallow, moderately clear with pebbles and sand particles along with other species of Aborichthys, Acanthocobitis, Barilius, Balitora, Botia, Crossocheilus, Garra, Neolissochilus, Pseudolaguvia, Psilorhynchus, Puntius, Schistura and Tor. The occurrences of these species indicate their range extension of Brahmaputra drainage, the Assam-Bhutan hill streams of Chirang District, Northeast India.

\section{ACKNOWLEDGEMENTS}

The authors are thankful to University Grants Commission's Special Assistance program for financial assistance and to Professor W. Vishwanath Singh of the department of Life Sciences, Manipur University, for access the museum.

\section{REFERENCES}

Blyth, E. (1858). Report of Curator, Zoological Department, for May, 1858. Journal of the Asiatic Society of Bengal, 27: 267-290.

Brooks, J. L. (2011). An Introduction to the Study of Fresh Water Biology. Asiatic Publishing House, Delhi 92, vii+107 pp.

Chaudhuri, B. L. (1919). Report on a small collection of fish from Putao (Hkamti Long) on the northern frontier of Burma, Records of the Indian Museum, 16: 271-287.

Chen, X. and Lundberg, J. G. (1995). Xiurenbagrus, a new genus of amblycipitid catfishes (Teleostei: Siluriformes), and phylogenetic relationships among the genera of Amblycipitidae. Copeia, 4: 780-800.

Day, F. (1878). The fishes of India; being a natural history of the fishes known to inhabit the seas and freshwaters of
India, Burma, and Ceylon. William Dowson \& Co., London, pp. 778.

Hamilton, F. (1822). An account of the fishes found in the river Ganges and its branches. Archibald Constable, Edinburgh and Hurst, Robinson, London: 405.

Hollister, G. (1934). Clearing and dyeing fishes for bone study. Zoologica, 12: 89-101.

Hora, S. L. (1933). Siluroid fishes of India, Burma and Ceylon, Part I. Loach-like fishes of the genus Amblyceps Blyth. Records of the Indian Museum, 35: 607-621.

Humtsoe, N. L. and Bordoloi, S. (2009). Study on torrential catfish Amblyceps apangi Nath and Dey 1989 (Teleostei: amblycipitidae) from Wokha district, Nagaland. Journal of Threatened Taxa, 1(2): 109-113.

Jayaram, K. C. (1999). The fresh water fishes of the Indian region. Narendra Publishing House, Delhi: pp. 551.

McClelland, J. (1842). On the Fresh water fishes collected by William Griffith, Esq., F. L. S. Madras Medical Service, during his travels under the orders of the Supreme Government of India, from 1835 to 1842. Calcutta Journal of Natural History, II: 560-589.

Misra, K. S. (1976). Teleostomi: Cypriniformes; Siluriformes. In: The Director, Zoological Survey of India (Ed.). The fauna of India and the adjacent countries pisces $\left(2^{\text {nd }}\right.$ edition) vol. III. The Controller of Publications, Delhi: $\mathrm{xxi}+367 \mathrm{pp}$.

Nath, P. and Dey, S. C. (1989). Two new fish species of the genus Amblyceps Blyth from Arunachal Pradesh, India. Journal of the Assam Science Society, 32: 1-6.

Nath, P. and Dey, S. C. (2000). Fish and Fisheries of North Eastern India (Arunachal Pradesh). Narendra Publishing House, Delhi: 217.

$\mathrm{Ng}, \mathrm{H}$. H. and Kottelat, M. (2000). A review of the genus Amblyceps (Osteichthyes: Amblycipitidae) in Indochina, with descriptions of five new species. Ichthyological Exploration of Freshwaters, 14: 335-348.

$\mathrm{Ng}, \mathrm{H}$. H. (2001). Amblyceps macropterus, a new species of Amblycipitid catfish (Osteichthys: Amblycipitidae) from Pakistan. Ichthyological Exploration of Freshwaters, 12: 201-204.

$\mathrm{Ng}$, H. H. (2005). Amblyceps carinatum, a new species of hillstream catfish from Myanmar (Teleostei: Amblycipitidae). Raffles Bulletin of Zoology 53 (2): 243-249.

Roberts, T. R. (1989). The freshwater fishes of Western Borneo (Kalimantan, Barat, Indonesia). Memoirs of the California Academy of Science, 14: 1-210.

Shaw, G. E. and Shebbeare, E. O. (1937). The fishes of northern Bengal. Journal Royal Asiatic Society of Bengal, Science, 5(3): 35-36

Sen, T. K. (1985). The fish fauna of Assam and the neighbouring North-eastern states of India. Records of Zoological Survey of India, Occasional paper No.64: 1216.

Talwar, P. K. and Jhingran, A. G. (1991). Inland Fishes of India and adjacent countries. In 2 vols. Oxford and IBH publishing House, New Delhi: xx+1158 pp.

Vishwanath, W. and Linthoingambi, I. (2007). Redescription of catfishes Amblyceps arunachalensis and Amblyceps apangi Nath and Dey (Teleostei: Amblyceptidae). Zoos' Print Journal, 22(4): 2662-2664.

Vishwanath, W. and Linthoingambi, I. (2008). Two new catfish species of the genus Amblyceps from Manipur, India (Teleostei: Amblycipitidae). Ichthyological Exploration of Freshwaters, 19(2): 167-174. 